\title{
PRINSIP-PRINSIP PENANGGULANGAN KEMISKINAN DI WILAYAH PESISIR UTARA JAWA TENGAH
}

\section{Need For Poverty Reduction In North Coastal Areas In Central Java}

\author{
Arif Sofianto \\ Badan Perencanaan Pembangunan Daerah, \\ Penelitian dan Pengembangan Provinsi Jawa Tengah \\ JI. Pemuda 127-133 Semarang, Telp. 0243515591 \\ *e-mail: areef_sofiant@yahoo.com \\ Diterima 12 April 2014- Disetujui 25 Mei 2015
}

\begin{abstract}
ABSTRAK
Masyarakat pesisir merupakan salah satu kelompok termiskin. Kebijakan-kebijakan yang telah dilaksanakan di kawasan pesisir sering mengakibatkan beberapa kondisi berupa perusakan ekologi, kesenjangan dan kemiskinan nelayan tradisional, serta ketergantungan masyarakat terhadap pemodal. Penelitian ini bertujuan untuk memahami kebutuhan penanggulangan kemiskinan pada wilayah pesisir sesuai dengan karakteristik dan kebutuhan masyarakat. Jenis penelitian adalah deskriptif kualitatif. Lokasi penelitian dilaksanakan di Kecamatan Juwana dan Margoyoso di Kabupaten Pati, serta Kecamatan Ulujami di Kabupaten Pemalang. Informan penelitian ini berjumlah 100 orang terdiri dari unsur pemerintah daerah, lembaga masyarakat, koperasi, nelayan, petambak, pengolah hasil perikanan dan petani. Teknik pengumpulan data menggunakan wawancara, FGD dan Observasi. Teknik analisis data menggunakan model yang dikembangkan oleh Spradley, yang merupakan kesatuan proses linear yang dimulai dari analisis domain, analisis taksonomi, analisis komponensial dan analisis tema budaya. Kesimpulan dari penelitian ini adalah model penanggulangan kemiskinan pada masyarakat pesisir utara Jawa Tengah berupa konsep pemberdayaan yang mengutamakan prinsip a). Komitmen pada keyakinan, nilai, adat kebiasaan, kepentingan bersama, b). Menciptakan keterbukaan, kejujuran, solidaritas dan pelibatan masyarakat.
\end{abstract}

Kata Kunci: kemiskinan, masyarakat pesisir, Jawa Tengah

\begin{abstract}
The coastal communities is one of the main groups of the poorest. The policies that have been implemented in coastal areas often result in some circumstances as ecological destruction, poverty gap and traditional fishing, as well as public dependence on financiers. This study aims to understand the need to reduce poverty in coastal areas according to the characteristics and needs of the community. This type of research is qualitative descriptive. The location of research in the Juwana and Margoyoso sub district in Pati Regency, and the Ulujami Subdistrict in Pemalang Regency. The informants of 100 people consisting of representatives from local government, community organizations, cooperatives, fishermen, farmers, fishpond farmers, and fish processors. The technique of collecting data using interviews, focus group discussions and observation. Data were analyzed using a model developed by Spradley, which is the unity of a linear process that starts from domain analysis, taxonomic analysis, componential analysis and analysis of cultural themes. The conclusion of this study is a model of addressing poverty in the north coast of Central Java community a concept that promotes empowerment principle a). Commitment to the beliefs, values, customs, common interests, b). Create transparency, honesty, solidarity and community involvement.
\end{abstract}

Keywords: poverty, coastal communities, Central Java 


\section{PENDAHULUAN}

Kemiskinan merupakan permasalahan global yang selalu menarik untuk dibicarakan dari berbagai sudut pandang teori, sudut pandang kewilayahan, dan memiliki beberapa varian penanggulangan. Kemiskinan memiliki dimenasi yang luas, baik struktural maupun kultural, individu maupun sosial, relatif maupun absolut, maupun dampak lain seperti masalah kewilayahan, sosial dan politik. Setiap individu maupun kelompok memiliki ciri khas tersendiri.

Masyarakat pesisir, terutama nelayan lekat dengan kemiskinan bahkan disebut kelompok miskin diantara yang miskin (Sipahelut, 2010). Menurut Kusumaningrum (2013) dalam studinya tentang kemiskinan masyarakat pesisir di Kabupaten Purworejo, bahwa kemiskinan nelayan terkait dengan masalah kompleks baik secara struktural, kultural maupun natural. Menurut Kusnadi dalam Sipahelut (2010) penyebab kemiskinan masyarakat nelayan dapat dikelompokkan menjadi internal dan eksternal. Sebab internal mencakup: (1) keterbatasan kualitas sumber daya manusia (SDM), (2) keterbatasan modal dan teknologi, (3) hubungan kerja kurang menguntungkan, (4) kesulitan diversifikasi usaha, (5) ketergantungan terhadap okupasi melaut, dan (6) gaya hidup boros. Adapun sebab eksternal meliputi: (1) kebijakan yang berorientasi produktivitas dan parsial, (2) sistim pemasaran yang merugikan, (3) kerusakan ekosistem, (4) peralatan tangkap yang tidak ramah lingkungan, (5) penegakan hukum yang lemah, (6) terbatasnya teknologi pengolahan, (7) terbatasnya peluang-peluang kerja non perikanan, (8) kondisi alam dan musim, dan (9) isolasi geografis.

Ketimpangan juga merupakan salah satu permasalahan penyebab kemiskinan. Hal ini, terutama berkaitan dengan keuntungan ekonomi dari pemanfaatan sumberdaya pesisir dan laut baru dinikmati oleh kelompok masyarakat tertentu seperti juragan kapal dan pengusaha perikanan, namun belum oleh masyarakat pesisir dan nelayan. Selain kesenjangan dalam pendapatan, kesenjangan dalam kepemilikan justru menjadi permasalahan yang lebih serius (Syarief, 2001). Akumulasi sumberdaya pada pihak-pihak tertentu mengarah pada deaksesasi oleh masyarakat. Misalnya saja dalam hal penangkapan, hanya yang memiliki kapal lebih besar dan teknologi yang lebih maju yang dapat menguasai sumberdaya laut. Menurut hasil penelitian Widodo (2011) tentang faktor penyebab kemiskinan masarakat pesisir di Kwanyar Barat, Kabupaten Bangkalan adalah rendahnya akses terhadap modal terutama modal finansial sehingga menyebabkan nelayan tidak mampu mengakses modal fisik berupa teknologi penangkapan yang lebih modern.

Desa-desa pesisir yang sebagian besar penduduknya bermata pencaharian sebagai nelayan, petambak, atau pembudidaya perairan, kebudayaan nelayan berpengaruh besar terhadap terbentuknya identitas kebudayaan masyarakat pesisir secara keseluruhan (Ginkel, dalam Kusnadi, 2010). Menurut Wahyudin (2003), karaktersitisk masyarakat pesisir dapat diidentifikasi berupa tergantung pada lingkungan, tergantung pada musim, tergantung pasar. Masyarakat nelayan/pesisir juga dikenal dengan perilaku: mengeksploitasi terus-menerus tanpa memahami batas-batasnya disertai dengan merusak ekosistem.

Di sisi lain terdapat juga yang mengeksploitasi dengan tindakan konservasi, seperti pelestarian terumbu karang, hutan bakau, dan mengoperasikan jaring yang ramah lingkungan (Kusnadi, 2010). Perilaku merusak dianut oleh sebagian besar nelayan untuk sumberdaya yang sifatnya terbuka, dan perilaku konservasi ditunjukkan oleh komunitaskomunitas adat atau komunitas lokal yang mengelola sumber daya perikanan untuk memperkuat kepentingan ekonomi kolektif (Kusnadi, 2010).

Kerentanan perubahan secara ekologis juga berpengaruh secara signifikan terhadap usaha perekonomian yang ada di wilayah tersebut, karena ketergantungan yang tinggi dari aktivitas ekonomi masyarakat dengan sumberdaya ekologis tersebut. Salahsatu contoh pertambahan jumlah penduduk yang tinggal di kawasan pesisir menyebabkan tekanan terhadap ekosistem mangrove yang ada (Auliyani et al., 2014). Ada tarik menarik 
antara yang mengeksploitasi alam dan yang memerlukan kelangsungan nafkah dari alam.

Temuan lainnya dari hasil penelitian Manumono (2008) bahwa abrasi tambak dan rob mengalami menyebabkan penurunan pendapatan petani tambak dan nelayan sehingga mereka mengalami perubahan perilaku yang bersifat negatif yaitu apriori, apatis dan mengalami gangguan jiwa. Sebagian petani dan nelayan yang hilang tambaknya beralih menjadi buruh serabutan, nelayan seser ataupun nelayan tangkap (sampan dan jaring), yang sebelumnya juragan berubah menjadi petani penggarap.

Berdasarkan hasil penelitian Primyastanto et al. (2010) bahwa faktor timbulnya perusakan lingkungan wilayah pesisir tersebut karena tingkat pendidikan yang rendah dan kurangnya pengetahuan penduduk tentang pentingnya menjaga lingkungan. Masalah yang terjadi di pesisir tersebut salahsatunya adalah kurangnya pemberdayaan masyarakat dan pengguna sumberdaya pesisir dan lautan. LSM dapat memainkan peran kunci dalam pengorganisasian sosial dengan bertindak sebagai fasilitator, katalisator, pelopor kepemimpinan dan pemasok kepemimpinan peralihan (Pieter, 2001). Sedangkan Hiariey (2013) menemukan bahwa strategi meningkatkan peran aktif masyarakat dalam pengelolaan wilayah pesisir adalah dengan pengelolaan wilayah pesisir berbasis masyarakat (co-management). Dalam strategi tersebut, masyarakat memiliki kewenangan cukup dalam pengelolaan dan terakomodasinya kepentingan masyarakat dalam proses pengelolaan. Sebagaimana disampaikan Ticoalu et al. (2013) bahwa keberhasilan program karena masyarakat, pemerintah dan pengusaha memiliki kontribusi yang relatif sama terhadap moral, ditinjau dari pemberdayaan masyarakat pesisir.

Faktor lain yang mempengaruhi keberhasilan suatu program pemberdayaan masyarakat di wilayah pesisir adalah kebijakan pemerintah. Sesuai hasil penelitian Syarief (2001) bahwa kebijakan pembangunan kelautan selama ini, cenderung mengarah kepada "produktivitas" memaksimalkan eksploitasi tanpa ada pengendalian. Kebijakan tersebut mengakibatkan beberapa kondisi berupa: a). overfishing, perusakan ekologi laut dan pantai, b). kesenjangan dan kemiskinan nelayan tradisional, c). ketergantungan masyarakat nelayan kecil/tradisional terhadap pemodal besar/ modern, antara nelayan dan pedagang, antara pherphery terdapat center, antara masyarakat dengan pemerintah. Menurut Tulungen (2001), pendekatan pengelolaan sumberdaya wilayah pesisir yang dapat menjadi rujukan adalah berbasis pemberdayaan masyarakat. Konsep ini telah menjadi pendekatan utama dalam pengelolaan sumberdaya pesisir di Indonesia sebagai bagian dari sistem pemerintahan yang desentralistis.

Menurut hasil penelitian Fitriansah (2012), keberhasilan pemberdayaan di pesisir berhasil dengan adanya penyadaran kepada masyarakat bahwa program yang mereka jalankan bukan semata-mata program dari pemerintah, tetapi juga menjadi program mereka sendiri. Terdapat tiga aktor yang memainkan perannya dengan sempurna yakni: pemerintah daerah sebagai pembina dan pengarah program, masyarakat lokal sebagai pelaksana utama seluruh kegiatan dan kelompok yang memfasilitasi hubungan kedua aktor secara transparansi dan terbuka.

Selanjutnya hasil penelitian Mardjoeki (2012) menyatakan bahwa pemberdayaan masyarakat pesisir perlu adanya kerja sama yang simultan dan lintas sektoral, pendekatan yang paling sesuai dengan kondisi tersebut adalah dengan cara pendekatan partisipatif yaitu suatu pendekatan yang melibatkan kerja sama antara masyarakat setempat dan pemerintah.

Demikian juga dengan Arviyanthi et al. (2014) bahwa faktor pendukung pemberdayaan adanya komitmen, lingkungan politik yang stabil, perda yang tidak memberatkan, masyarakat yang ingin berubah, ada kelompok yang peduli lingkungan, keterpaduan dengan visi dan misi dinas. Hasil penelitian Indarti et al. (2013) juga menyatakan bahwa penguatan kelembagaan koperasi nelayan sebaiknya diawali dengan mengorganisir nelayan yang mempunyai kepentingan ekonomi dan komitmen yang sama untuk bergabung dalam organisasi koperasi. 
Oleh sebab itu, penanggulangan permasalahan kemiskinan di wilayah pesisir tidak mengabaikan aspek pemberdayaan, seperti aspek sosial budaya dan kebutuhan riil masyarakat. Menurut Kusnadi (2010) masyarakat nelayan (pesisir) memiliki ciri-ciri perilaku sosial yang dipengaruhi oleh karakteristik kondisi geografis dan mata pencaharian penduduknya, yaitu: (1) Etos kerja tinggi untuk memenuhi kebutuhan hidup dan mencapai kemakmuran; (2) Kompetitif dan mengandalkan kemampuan diri untuk mencapai keberhasilan; (3) Apresiasi terhadap prestasi seseorang dan menghargai keahlian; (4) Terbuka dan ekspresif, sehingga cenderung "kasar"; (5) Solidaritas sosial yang kuat dalam menghadapi ancaman bersama atau membantu sesama ketika menghadapi musibah; (6). Kemampuan adaptasi dan bertahan hidup yang tinggi; (7) Bergaya hidup "konsumtif"; (8). Demonstratif dalam harta-benda (emas, perabotan rumah, kendaraan, bangunan rumah, dan sebagainya) sebagai manifestasi "keberhasilan hidup"; (9). "Agamis", dengan sentimen keagamaan yang tinggi, dan; (10). "Temperamental", khususnya jika terkait dengan "harga diri".

Provinsi Jawa Tengah memiliki wilayah yang disebut Pantura (Pantai Utara) yang erat dengan permasalahan kemiskinan dan karakter masyarakat sebagaimana dikemukakan di atas. Para sejarawan umumnya mengkategorikan pesisir pulau Jawa dibagi ke dalam dua kategori utama yaitu Pesisiran Barat meliputi Demak, Kendal, Batang, Pekalongan, Pemalang, Wirodesa, Tegal, dan Brebes, serta Pesisiran Timur meliputi Cengkal Sewu, Surabaya, Gresik, Sedayu, Tuban, Lasem, Juwana, Pati, Kudus, dan Jepara (Itha, 2013).

Masyarakat di Kabupaten Pati merupakan stereotip Pantura Jawa Tengah bagian timur dan Kabupaten Pemalang dapat mewakili karakter masyarakat Pantura Jawa Tengah bagian barat yang dapat dianggap sebagai contoh tersebut di atas. Oleh sebab itu, penelitian ini diperlukan dalam rangka mengupas berbagai karakter kemiskinan masyarakat pesisir untuk dalam memahami penanggulangan kemiskinan yang dibutuhkan dalam di wilayah pesisir utara Jawa Tengah.

\section{METODE PENELITIAN}

\section{Lokasi dan Waktu Penelitian}

Lokasi penelitian dilaksanakan di Pesisir PantaiUtara Jawa Tengah, khususnya Kabupaten Pemalang dan Kabupaten Pati. Di Kabupaten Pemalang penelitian difokuskan di Kecamatan Ulujami meliputi Desa Mojo, Pesantren, dan Limbangan. Di Kabupaten Pati difokuskan di Kecamatan Juwana, Desa Bakaran Kulon dan Desa Bajomulyo.

\section{Responden Penelitian}

Responden penelitian ini berjumlah 100 orang tersebar di Kabupaten Pemalang dan Kabupaten Pati. Kemudian diambil sebanyak satu-dua Kecamatan, dan setiap Kecamatan diambil sebanyak dua-tiga desa. Responden terdiri dari masyarakat dari berbagai kelompok profesi dan sosial ekonomi. Ditiap desa yang menjadi unit penelitian, terdiri dari nelayan tangkap sebanyak tiga orang, pembudidaya tambak sebanyak tiga orang, pengolah hasil perikanan/laut sebanyak dua orang, Usaha Mikro Kecil dan Menegah (UMKM) berbasis perikanan sebanyak dua orang, Perwakilan HNSI sebanyak dua orang, Pengurus KUD sebanyak satu orang, Pengelola TPI sebanyak satu orang, Camat, Kepala Desa, Aparat Bappeda sebanyak satu orang, Aparat Dinas Kelautan sebanyak satu orang, Aparat Bapermades sebanyak satu orang, Aparat Dinas Pariwisata sebanyak satu orang, Tokoh Budaya sebanyak satu orang, Perwakilan Lembaga Swadaya Masyarakat (LSM) (pemberdayaan nelayan, lingkungan pantai, UMKM) sebanyak satu orang

\section{Jenis dan Sumber Data}

Data dalam penelitian ini data primer dari hasil wawancara dan data lapangan. Sedang data sekunder berupa peraturan-peraturan, buku-buku yang berkaitan dengan masyaakat pesisir dari dinas instansi terkait serta hasilhasil penelitian dari lembaga penelitian majupun perguruan tinggi yang sudah ada gtentang masalah dan lokasi penelitian. 


\section{Metode Pengumpulan Data}

Beberapa metode pengumpulan data yang dipergunakan adalah:

- Teknik wawancara dengan menggunakan daftar pertayaan dan wawancara secara mendalam/ in-depth interview dengan responden. Sedangkan daftar pertanyaan (angket) yang digunakan secara terbuka.

- Focussed Group Discussion (FGD) dilakukan untuk memeprdalam penggalian data dari masyarakat.

- Observasi. Teknik ini untuk mengamati hasil program pemberdayaan yang sudah dilakukan, kelembagaan masyarakat serta relasi sosial budaya masyarakat.

\section{Metode Analisis Data}

Penelitian ini merupakan penelitian deskriptif dengan pendekatan kualitatif. Analisis yang digunakan dalam penelitian ini adalah analisis yang dikembangkan oleh Spradley seperti yang dikutip Iskandar (2008) dan Sugiyono (2009), yang terdiri dari Analisis Domain, Analisis Taksonomi, Analisis Komponensial, dan Analisis Tema Budaya

\section{HASIL DAN PEMBAHASAN}

Masyarakat pesisir dikenal lebih keras dalam berusaha, fokus pada pekerjaan yang cepat menghasilkan pendapatan, namun juga lebih mudah membelanjakan pendapatan yang mereka terima. Dalam pemilihan pekerjaan, mayoritas masyarakat pesisir lebih memilih pekerjaan yang cepat menghasilkan uang. Sebagian besar responden menyatakan bahwa dalam memilih jenis pekerjaan pertimbangannya adalah cepat menghasilkan uang.

Di Kabupaten Pati untuk menghasilkan uang langsung menjual hasil tangkapan kepada bakul tidak diolah menjadi hasil olahan yang langsung bisa dikonsumsi. $\mathrm{Di}$ Kabupaten Pemalang cepat menghasilkan uang dengan berusaha berdagang masakan/lauk-pauk, mancing kepiting, ngarad, berjualan ikan segar dan sejenisnya. Sebagian mereka berusaha karena ingin cepat menjadi kaya
Pekerjaan sampingan merupakan salah satu upaya masyarakat pesisir untuk mencukupi kebutuhan mereka. Pada saat paceklik, ada beberapa upaya yang dilakukan oleh masyarakat pesisir, sebagian memilih mencari pekerjaan tambahan, sebagian lainnya berhutang, sebagian berhemat dan sebagian lagi yang pasrah dengan kondisi tersebut. Alternatif paling banyak saat paceklik adalah mencari pekerjaan lain, sementara sebagian lagi berhutang dengan harapan ketika musim panen akan dapat terbayar. Para nelayan mengaku mereka terpaksa memilih pekerjaan sebagai nelayan karena merasa cepat menghasilkan.

Tidak semua masyarakat pesisir mengusahakan pekerjaan sampingan, sebagian mereka tidak memiliki pekerjaan sampingan karena berbagai keterbatasan dan alasan personal. Separuh lebih responden menyatakan masyarakat pesisir memiliki pekerjaan lain selain di sektor utama (tambak, tambak, pengolahan, UMKM). Pekerjaan sampingan menjadi penting ketika musim paceklik. Sementara sebagian lainnya tidak memiliki pekerjaan sampingan karena merasa pekerjaan utama sudah mampu mencukupi kebutuhannya, atau karena tiadanya kesempatan dan kemampuan menciptakan pekerjaan lain.

Dalam sektor pengolahan perikanan, jenis ikan/olahan yang paling banyak dibudidayakan dan diolah adalah ikan bandeng karena modal tidak terlalu besar, mudah diperoleh, dan pasar luas. Meskipun paling banyak diolah diwilayah penelitian, namun jumlah bandeng yang diolah hanya sebagian kecil dibanding jumlah panen mereka, sebagian besar justru diolah diluar kota.

Di pesisir Kabupaten Pemalang, selain nelayan dan bertambak, sebagian masyarakat juga bertani hortikultura baik sayur maupun buah-buahan serta bunga melati. Kendala yang dialami menurut Wasjud (petani di Ulujami) bahwa:

"selama ini kendala petani adalah harga jual produk jauh dari biaya produksi, misalnya harga tomat hanya $200 / \mathrm{kg}$. Para petani membentukkelompok, tetapi perlu bimbingan pasar, menyelaraskan 
dengan pasar industri. Petani juga kalah teknologi dengan daerah lain (Jatim) sehingga perlu studi banding dan pelatihan"

Pada tingkat penghasilan, masyarakat pesisir cenderung dipengaruhi oleh musim. Pada saat tidak musim, pendapatan mengalami penurunan yang cukup besar, hampir separuhnya (42\%). Hal ni menunjukkan ketergantungan besar terhadap musim.

Terkait dengan gaya hidup, masyarakat pesisir dinilai cenderung boros atau "konsumtif". Mereka dianggap sering mempertontonkan keberhasilan ekonomi mereka. Mereka juga lebih mudah membelanjakan uang mereka, terutama saat musim panen. Menurut responden di Kabupaten Pemalang, masyarakat pesisir karena merasa mudah menghasilkan uang, dalam gaya hidup berbusana, pola makan, tidak memikikirkan alokasi untuk menabung. Dari uang yang dihasilkan sebagian besar dibelanjakan. Adapun sebagian lagi tidak demikian, pengeluaran agak banyak jika ada pendapatan lebih saja.

Baik di Kabupaten Pati maupun Kabupaten Pemalang, kecenderungan masyarakat pesisir terhadap kegiatan hiburan sangat tinggi. Sebagaimana diungkapkan oleh Pri (nelayan Bajulmulyo, Juwana) bahwa setiap tahun warga desa menyelenggarakan acara sedekah laut yang diiringi dengan hiburan yang paling tidak menghabiskan dana sampai 450 juta rupiah.

Selain kondisi sosial dan ekonomi di atas, ada beberapa kendala dan halangan fisik/ infrastruktur serta lingkungan. Kendala minimnya infrastruktur serta kerusakan lingkungan mewarnai kondisi masyarakat pesisir. Minimnya akses jalan dan jembatan, telekomunikasi, dan energi kerap mewarnai kondisi mereka. Sebagai contoh jalan menuju tambak bandeng di Bakaran Kulon, Juwana masih kurang lancar dan mengganggu rantai dingin penjualan ikan mereka. Isu lingkungan lainnya berupa abrasi di tepi pantai serta pengendapan lumpur di saluran tambak. Isu lainnya terkait keamanan lingkungan serta produk olahan pangan hasil produksi masyarakat pesisir.
Dengan kehidupanyang keras, masyarakat pesisir memiliki semangat kerja tinggi untuk memenuhi kebutuhan hidup dan mencapai kemakmuran. Sebagian besar menyatakan bahwa masyarakat pesisir relatif memiliki semangat kerja yang tinggi. Di Kabupetan Pati, semangat kerja tinggi terlihat dari banyak yang meninggalkan keluarga untuk mencari ikan di laut, bekerja keras walaupun cuaca ekstrem mereka tetap mencari ikan. Bagi petambak penyewa bisa merangkap pekerja untuk memenuhi kebutuhan hidup. Di Kabupaten Pemalang, ada masyarakat yang memiliki semangat tinggi, belajar, kerja keras, kreatif membuat peralatan, pengolahan dan budidaya. Di sisi lain masih adanya masyarakat yang mengharapkan bantuan dari pemerintah, mengharapkan bantuan dair pihak lain.

Sikap mental lainnya adalah kompetitif, mencapai keberhasilan atas kemampuan sendiri. Masyarakat pesisir memiliki etos kerja yang mandiri dan berani mengambil tantangan. Namun ada sebagian yang tidak kompetitif dan lebih memilih kompromi. Di Kabupaten Pati, orang berani berupaya untuk maju, tidak takut gagal, jika berhasil akan menikmati, tetapi bila tidak berhasil sudah merasa biasa hidup susah. Mereka sering tukar pengalaman, bekerja keras, berani berusaha keras. Di sisi lain sebagian merasa hidup nyaman apa adanya, berusaha semampunya untuk menghidupi keluarga. Di Kabupaten Pemalang masyarakat kebanyakan memiliki pekerjaan lebih dari satu macam, yang penting bisa mencukupi kebutuhan seharihari. Mereka juga merantau ke luar kota untuk mencari penghasilan tambahan.

Dalam memenuhi kebutuhan hidupnya, masyarakat pesisir lebih berani mengambil resiko dalam berusaha. Mereka berani mengambil resiko seperti berhutang, berganti komoditas, dan sebagainya untuk keberhasilan usaha. Di Kabupaten Pati banyak yang mengambil hutang bank untuk menambah permodalan sampai miliaran rupiah, mereka berani berspekulasi dalam usaha. Rata-rata memilki usaha dengan modal besar seperti kapal dan tambak. Mereka juga berani mencoba suatu hal yang baru yang lebih mendatangkan untung. Di Kabupaten Pemalang berani ambil resiko contoh budidaya 
udang vaname dengan modal pinjaman dari bank atau koperasi, tidak mempedulikan berhasil tidaknya usaha. Selama masih ada pihak yang memberikan hutang, tetap berani berhutang untuk usaha. Para nelayan biarpun cuaca kurang mendukung tetap berani melaut.

Dalam berusaha, persaingan antarmasyarakat cenderung lebih rendah, hanya terjadi dalam kasus-kasus tertentu saja, selebihnya bekerjasama. Menuurt penuturan responden baik di Kabupaten pemalang maupun Kabupaten Pati, persaingan tidak terlalu tinggi. Di Kabupaten Pati persaingan terjadi pada warga yang berlomba-lomba dalam meningkatkan hasil produksi. Selain itu ada yang bersaing dalam harga sewa lahan tambak. Tetapi mereka menyatakan melakukan persaingan dengan sehat. Sebagian menyatakan bahwa tidak terjadi persaingan karena kesenjangan ekonomi tidak menyolok, bahkan para nelayan dalam mencari ikan mereka saling berkomunikasi dengan memakai alat komunikasi SSB (Single Side Band Modulation). Di tambak meraka bahkan bersama untuk mencari kebutuhan air tambak. Pada umumnya banyak yang bekerja secara kelompok sehingga lebih membutuhkan kerjasama daripada pesaingnya.

Kemudian Kabupaten Pemalang hampir sama, ada persaingan dalam meningkatkan kesejahteraan, mereka menunjukkan kekayaan dan keberhasilan, melakukan pembelian barangbarang. Masyarakat juga cenderung bersaing dalam meningkatkan produksi pertanian baik petani sawah maupun tambak. Namun mereka menyatakan bersaing secara sehat. Di sisi lain ketika menghadapi kesulitan ada upaya kerjasama.

Masyarakat pesisir cenderung saling bersaing menunjukkan keberhasilan. Ketika panen mereka membelanjakan untuk berbagai barang, kendaraan dan lainnya, sehingga rasa saling menunjukkan keberhasilan (dengan kepemilikan) beriringan dengan rasa saling membantu saat kesulitan. Meskipun demikian, solidaritas masih tetap tinggi, ada bantuan berupa pinjaman dari tetangga, tetapi hanya untuk mereka yang dipercaya. Hanya 36 persen yang menyatakan mendapatkan bantuan dari tetangga saat paceklik.

Sesuai dengan hasil penelitian di atas, ada beberapa karakteristrik yang bisa menjadi potensi dalam penanggulangan kemiskinan yang dilakukan dengan konseep pemberdayaan. Ciri umum masyarakat pesisir adalah komitmen pada nilai adat dan tradisi yang mereka yakini cukup kuat. Mereka rela berkorban demi terjaganya nilai dan adat tersebut. Acara sedekah laut, ruwatan, sedekah bumi mislanya, selalu dilaksanakan setiap tahun. Sumberdaya dana, tenaga waktu yang dibutuhkan cukup besar, namun masyarakat sukarela mendukungnya. Acara sedekah kaut yang kemudian diiringi dengan hiburan dananya mencapai ratusan juta rupiah, namun dengan mudah bisa didapatkan melalui iuran warga. Dana didapat dari iuran tiap musim panen baik dalam bentuk ikan maupun uang. Dari peristiwa tersebut Nampak bahwa adanya swadaya, kepedulian, sukarela tercipta dari komitmen terhadap nilai dan adat.

Karakter lainnya adalah keterbukaan, kejujuran, solidaritas dan pelibatan masyarakat. Dari beberapa contoh keberhasilan pengelolaan program dana perguliran, sifat-sifat tersebut menjadi pendorongnya. Sebuah program haruslah memuat kejelasan sasaran, prioritas dan pengelolaan. Dengan adanya kredibilitas tersebut maka program akan mendapatkan dukungan dari masyarakat.

Secara spesifik lokasi, berdasarkan tanggapan responden dan hasil pengumpulan data di lapangan, ada beberapa karakter yang menonjol pada masyarakat pesisir. Karakter tersebut meliputi ciri-ciri umum, perilaku ekonomi, serta bagaimana merumuskan strategi pemberdayaan yang tepat.

Ciri umum masyarakat pesisir di Kabupaten Pati dikaitkan dengan sifat dan perilaku seharihari, keyakinan serta kondisi sosial ekonomi. Masyarakat pesisir dipandang memiliki sifat jujur, amanah, lugas, memegang teguh prinsip dan komitmen, terbuka, suka bergotong royong, berjiwa sosial, serta ekspresif. Masyarakat pesisir juga dikenal lebih agamis. Di sisi lain, masyarakat pesisir juga dikenal mudah emosi, temperamental, berkarakter keras dan berbicara 
tegas. Masyarakat pesisir juga cenderung berpendidikan rendah/kurang memperhatikan pendidikan.

Masyarakat pesisir di wilayah penelitian memiliki semangat kerja tinggi, pekerja keras, ulet, kompetitif, berani ambil resiko, tidak mudah putus asa. Sikap tersebut didukung oleh kejujuran, semangat kerjasama/gotongroyong, serta kemauan berkelompok. Karakter tersebut di atas, merupakan salahsatu penopang keberhasilan mereka dalam bidang perekonomian. Semangat wirausaha juga tinggi sehingga dapat menciptakan lapangan pekerjaan. Di dalam melakukan usaha mereka juga mau berubah memanfaatkan teknologi/ cara baru dalam meningkatkan bidang usahanya. Di dalam manajemen usaha, berani mengambil resiko dalam permodalan, pinjaman perbankan, pinjaman koperasi dan dana perguliran sangat dinamis.

Masyarakat pesisir berani berspekulasi dalam berusaha. Kebanyakan masyarakat pesisir sangat tergantung dari perbankan atau lembaga keungan lainnya. Prinsip masyarakat pesisir adalah selama masih ada pihak yang dihutangi, mereka tetap berusaha meski dengan hutang yang banyak. Namun sebagian masyarakat pesisir juga mengalami masalah kurangnya bantuan permodalan.

Selain beberapa karakter yang mendukung perekonomian, beberapa karakter teridentifikasi dapat menghambat perekonomian seperti boros, sulit berubah, dan kurang mempedulikan masa depan. Masyarakat sebagian masih kurang kompetensi usaha serta kapasitas pendidikan yang kurang. Masyarakat pesisir juga dianggap kurang memiliki pengetahuan tentang teknologi, agak sulit menerima perubahan aturan, sulit menerima sesuatu yang baru. Biasanya untuk menerima hal baru, masyarakat pesisir perlu ada pemahaman terlebih dahulu untuk menerima yang baru, terutama contoh nyata keberhasilan. Masyarakat kebanyakan belum menerapkan cara atau teknik usaha yang baik. Masyarakat pesisir juga dikenal keras dan tegas, tetapi kadang menjurus kepada perilaku yang temperamental serta sensitif sehingga menyebabkan potensi konflik tinggi.
Sikap mental lainnya yang kurang mendukung usaha adalah sebagian masyarakat tidak ramah lingkungan. Mereka memanfatakan sumberdaya alam tanpa memperhatikan kelestarian. Selain itu, upaya untuk menjaga kelestarian lingkungan agar usaha mereka bisa terus berjalan juga masih kurang. Di Kabupaten Pemalang, ciri utama masyarakat pesisir juga terkait dengan sifat dan perilaku sehari-hari, keyakinan dan kondisi sosial masyarakatnya. Masyarakat pesisir di Kabupaten Pemalang dipandang memiliki solidaritas tinggi. Selain itu, mereka dianggap lebih ramah, masyarakat pesisir dianggap mudah beradaptasi dengan pendatang. Sama dengan kebanyakan masyarakat pesisir lainnya, masyarakat pesisir Kabupaten Pemalang cenderung berperilaku keras, cenderung berbahasa kasar dan arogan, serta emosional. Seperti masyarakat pesisir pada umumnya, relatif lebih agamis dibandingkan masyarakat di daerah lain.

Dari beberapa penjelasan di atas, karakter yang mendukung perekonomian pada masyarakat pesisir adalah cenderung suka bekerja keras, memiliki semangat tinggi. Selain itu, mereka memandang baik persaingan sebagai salahsatu langkah memajukan usaha. Masyarakat pesisir juga memiliki etos untuk menjadi pengusaha atau membuka lapangan kerja. Sedangkan karakter yang dapat menghambat perekonomian antara lain etos kerja menurun jika menghadapi kesulitan, seperti ketika musim badai. Perilaku keseharian masyarakat pesisir cenderung konsumtif, jika mendapatkan uang lebih langsung dibelanjakan dengan segera.

Berdasarkan penjelasan-penjelasan di atas, maka ada beberapa upaya perubahan atau strategi pemberdayaan masyarakat yang bisa dilaksanakan dalam upaya penanggulangan kemiskinan di pesisir. Strategi tersebut berupa peningkatan kualitas SDM, pemberian insentif serta akses. Beberapa strategi yang bisa dilakukan adalah:

1. Meningkatkan kapasitas SDM dengan cara memberikan pelatihan, pencerahan dan keahlian sehingga bisa berwirausaha. Mengubah mindset dari jiwa pekerja 
menjadi pengusaha, meningkatkan kemampuan masyarakat pesisir dengan membudidayakan potensi yang ada.

2. Memberikan penyuluhan teknologi yang tepat dalam bidangnya masing-masing, serta perlu adanya pemberdayaan baik keetrampilan maupun permodalan. Pelatihan-pelatihan terutama pengolahan hasil produksi dari IKM (Industri Kecil dan Menengah), pelatihan-pelatihan budidaya tambak dan sejensinya yang dibutuhkan masyarakat. Pelatihan tersebut perlu disertai dengan contoh dan praktik langsung.

3. Memberdayakan kelompok masyarakat (tani, nelayan, dII) sebagai sarana kagiatan sosial dan ekonomi, serta hubungan pemerintah dan masyarakat. Selain itu, KUD (Koperasi Unit Desa) juga bisa dimanfaatkan melalui sebagai sarana pemberdayaan. Meningkatkan apresiasi pemerintah terhadap kelompok yang berprestasi supaya kelompok saling bersaing/berlomba dalam prestasi, tidak hanya peminta bantuan yang menumbuhkan ketergantungan. Pembinaan dan sosialisasi peemrintah perlu dilakukan melalui lembaga-lembaga yang ada, seperti musyawarah dusun, kelompok pengajian, PKK (Peningkatan Kesejahteraan Keluarga) dan kegiatan pemuda (karang taruna).

4. Pembukaan akses permodalan, seperti pembentukan dan penguatan koperasi, LKM, dan simpan pinjam. Masyarakat juga perlu dibantu dalam mempermudah akses perbankan.

5. Transfer teknologi baru dalam mengembangkan usahanya

6. Adanya informasi pemasaran yang jelas dari dinas/instansi yang memfasilitasi pemasaran produk.

7. Pemerintah memfasiltasi prasarana yang dibutuhkan pelaku kegiatan usaha (misalnya di tambak; prasarana jalan, jembatan penghubung).

8. Adanya kebersamaan pemerintah desa dengan kelompok kurang untuk mewujudkan pembangunan perekonomian desa. Semua bantuan dari instansi manapun diharapkan masuk ke rekening desa sehingga pemerintah desa ikut bertanggungjawab dalam kemajuan perekonomian desa. Bantuan bisa dikembangkan kelompok masing-masing dan desa ikut bertanggungjawab dalam kegiatan tersebut

Oleh sebab pencerahan atau internalisasi nilai-nilai pembaharuan pada masyarakat pesisir harus dilakukan upaya pendidikan, pemahaman, penyadaran secara berkelanjutan sehingga mereka benar-benar memahami dan mendukung perubahan. Sebuah program harus mengandung nilai-nilai pembaharuan yang yang harus diinternalisasi melalui proses tersebut. Masyarakat akan sukarela mendukung keberhasilan program jika mereka meyakini nilai-nilainya. Masyarakat harus tahu manfaat dan kegunaan suatu perubahan bagi perbaikan kehidupan mereka.

\section{KESIMPULAN DAN IMPLIKASI KEBIJAKAN}

\section{Kesimpulan}

Prinsip-prinsip penanggulangan kemiskinan di kawasan pesisir utara Jawa Tengah yang dibutuhkan dalam pemberdayaan masyarakat, yaitu:

1. Berbasis pada kearifan lokal, seperti nilai, adat kebiasaan, tata nilai dan norma yang diyakini kebenarannya. Dalam konteks pemberdayaan, kondisi tersebut dapat ditanamkan melalui pencerahan atau internalisasi nilai-nilai pembaharuan. Kepada masyarakat pesisir harus dilakukan upaya pendidikan, pemahaman, penyadaran secara berkelanjutan sehingga mereka benar-benar memahami dan mendukung perubahan. Sebuah program harus mengandung nilai-nilai pembaharuan yang yang harus diinternalisasi melalui proses tersebut. Masyarakat akan sukarela mendukung keberhasilan program jika mereka meyakini nilai-nilainya. Masyarakat harus tahu manfaat dan kegunaan suatu perubahan bagi perbaikan kehidupan mereka.

2. Bersandar pada nilai sosial keterbukaan, kejujuran, solidaritas dan pelibatan masyarakat. Dari beberapa contoh keberhasilan pengelolaan dana perguliran, sifat-sifat tersebut menjadi pendorongnya. Sebuah program haruslah memuat kejelasan sasaran, prioritas dan pengelolaan. 
Dengan adanya kredibilitas tersebut maka program akan mendapatkan dukungan dari masyarakat.

\section{Implikasi Kebijakan}

Terdapat beberapa hal yang perlu menjadi catatan penting terkait pelaksanaan programprogram pemerintah di wilayah pesisir, baik di Kabupaen Pati maupun di Kabupaten Pemalang sebagai berikut:

1. Kegiatan diharapkan membantu masyarakat pesisir untuk meningkatkan kapasitasnya, baik keterampilan, permodalan maupun pemasaran.

2. Kegiatan diharapkan menghasilkan perubahan dalam kehidupan masyarakat, baik dalam bentuk perubahan cara kerja termasuk pemanfaatan teknologi dan memanfaatkan waktu luang mereka.

3. Program kegiatan yang ada diharapkan memberikan dampak sosial dan ekonomi melalui pemberdayaan potensi lokal.

4. Untuk pasca kegiatan pembinaan seyogyanya terus dilakukan agar terdapat keberlanjutan (sustainability).

\section{UCAPAN TERIMA KASIH}

Penulis mengucapkan terimakasih kepada berbagai pihak atas keterlibatan dan bantuan baik secara material maupun non material sehingga karya tulis ini dapat diselesaikan dengan baik. Untuk itu penulis mengucapkan terima kasih yang sebesar-besarnya kepada sekretariat redaksi Buletin Marina Sosial EKonomi Kelautan dan Perikanan.

\section{DAFTAR PUSTAKA}

Arviyanthi, E. P., M. Suryaningsih dan T. Yuniningsih. 2014. Strategi Pemberdayaan Masyarakat Pesisir Secara Terpadu Di Kota Semarang (Studi Kasus Di Kelurahan Mangunharjo). Jurusan Administrasi Publik Fakultas IImu Sosial dan IImu Politik Universitas Diponegoro. http//www.fisip.undip.ac.id

Auliyani, D., B. Hendrarto dan Kismartini. 2014. Partisipasi Masyarakat dalam Rehabilitasi Mangrove di Beberapa Desa Pesisir Kabupaten Rembang: Tinjauan Berdasarkan Tahap Perencanaan. Maspari Journal. Volume 6 Nomor 1 Tahun 2014. Hal. 13-19
Fitriansah, H. 2012. Keberlanjutan Pengelolaan Lingkungan Pesisir Melalui Pemberdayaan Masyarakat di Desa Kwala Lama Kabupaten Serdang Bedagai. Jurnal Pembangunan Wilaah dan Kota. Volume 8 Nomor 4. Desember 2012. Hal. 360-370

Hiariey, L. S. 2013. Peran Serta Masyarakat Pemanfaat Pesisir Dalam Pengelolaan Wilayah Pesisir Teluk Ambon Dalam. Jurnal Matematika. Sains. dan Teknologi. Volume 14 Nomor 1. Maret 2013. Hal. 48-61

Indarti, I. dan D. S. Wardana. 2013. Metode Pemberdayaan Masyarakat Pesisir Melalui Penguatan Kelembagaan Di Wilayah Pesisir Kota Semarang. Benefit; Jurnal Manajemen dan Bisnis Volume 17. Nomor 1. Juni 2013. Hal. 75-88

Itha. 2013. Budaya Masyarakat Pesisir. http:// ithakelautan.blogspot.co.id. Rabu. 22 Mei 2013

Kusnadi. 2010. Kebudayaan Masyarakat Nelayan. Makalah disampaikan dalam kegiatan JELAJAH BUDAYA TAHUN 2010. dengan tema "Ekspresi Budaya Masyarakat Nelayan di Pantai Utara Jawa". yang diselenggarakan oleh Balai Pelestarian Sejarah dan Nilai Tradisional. Kementeian Kebudayaan dan Pariwisata. di Yogyakarta. tanggal 12-15 Juli 2010

Kusumaningrum, A. 2013. Kebijakan Pembangunan Dalam Pengentasan Kemiskinan Masyarakat Pesisir. Agriekonomika. Volume 2. Nomor 1. April.2013. Hal 13-26

Manumono, D. 2008. Perubahan Perilaku Masyarakat Kawasan PesisirAkibat Penurunan Pendapatan Sebagai Dampak Abrasi dan Rob di Kabupaten Demak. Makalah disampakan dalam Seminar Nasional "Dinamika Pembangunan Pertanian dan Perdesaan: Tantangan dan Peluang bagi Peningkatan Kesejahteraan Petani”. diselenggarakan oleh Pusat Analisis Sosial Ekonomi dan Kebijakan Pertanian. Departemen Pertanian. Bogor. 19 Nopember 2008

Mardjoeki, H. 2012. Pemberdayaan Masyarakat Pesisir Pantai Utara Daerah Kabupaten Cirebon. Jurnal Ekonomi Issn: 2302-7169 Vol. 1 No. 1 September-Desember 2012. Hal. 52-57

Pieter, T. 2001. Peran Lembaga Swadaya Masyarakat Dalam Praktek Pengelolaan Pesisir Secara Terpadu. Prosiding Pelatihan Pengelolaan Wilayah Pesisir Terpadu. Pusat Kajian Sumberdaya Pesisir dan Lautan Institut Pertanian Bogor. 29 Oktober - 3 November 2001 
Primyastanto, M., R. P. Dewi dan E. Susilo. 2010. Perilaku Perusakan Lingkungan Masyarakat Pesisir Dalam Perspektif Islam (Studi Kasus Pada Nelayan dan Pedagang Ikan Di Kawasan Pantai Tambak. Desa Tambakrejo. Kecamatan Wonotirto. Kabupaten Blitar Jawa Timur). Jurnal Pembangunan dan Alam Lestari Vol. 1 No. 1 Tahun 2010

Sipahelut, M. 2010. Analisis Pemberdayaan Masyarakat Nelayan di Kecamatan Tobelo Kabupaten Halmahera Utara. Tesis Sekolah Pascasarjana Institut Pertanian Bogor.

Syarief, E. 2001. Pembangunan Kelautan Dalam Konteks Pemberdayaan Masyarakat Pesisir. Majalah PPITh 2001IEdisi-25

Ticoalu, D.E.B.S., E. Reppie dan A. T. R. Telleng. 2013. Analisis kebijakan pemberdayaan masyarakat perikanan tangkap di Kota Manado. Jurnal IImu dan Teknologi Perikanan Tangkap Volume 1 Nomor 3. Juni 2013. 76-80

Tulungen, J. J. 2001. Program Pengelolaan Sumberdaya Wilayah Pesisir Terpadu Dan Berbasis Masyarakat: Telaah Kasus di Kabupaten Minahasa. Sulawesi Utara. Prosiding Pelatihan Pengelolaan Wilayah Pesisir Terpadu. Pusat Kajian Sumberdaya Pesisir dan Lautan Institut Pertanian Bogor. 29 Oktober - 3 November 2001

Wahyudin, Y.2003. Sistem Sosial Ekonomi Dan Budaya MasyarakatPesisir. Makalah disampaikan pada pelatihan Pengelolaan Kawasan Konservasi Perairan, tanggal 5 Desember 2003 di Kampus Pusdiklat Kehutanan.

Widodo, S. 2011. Strategi Nafkah Berkelanjutanbagi Rumah Tangga Miskin Di Daerah Pesisir. Makara. Sosial Humaniora. Vol. 15. No. 1. Juli 2011, Hal. 10-20 